\title{
Assessment and Mapping of Soil pH and Available Phosphorus Status in Wuchale District, North Shewa Zone, Oromia
}

\author{
Endale Bedada*, Ajema Lemma, Wubalem Abera, Abera Donis, Dereje Girma \\ Fitche Agricultural Research Center, Fitche, Ethiopia \\ Email address: \\ endenat2008@gmail.com (E. Bedada) \\ ${ }^{*}$ Corresponding author \\ To cite this article: \\ Endale Bedada, Ajema Lemma, Wubalem Abera, Abera Donis, Dereje Girma. Assessment and Mapping of Soil pH and Available \\ Phosphorus Status in Wuchale District, North Shewa Zone, Oromia. American Journal of Environmental Science and Engineering. \\ Vol. 4, No. 1, 2020, pp. 1-6. doi: 10.11648/j.ajese.20200401.11
}

Received: March 19, 2020; Accepted: April 7, 2020; Published: April 29, 2020

\begin{abstract}
The lack of site specific fertilizer recommendation to replenish declining soil fertility has been the major challenge to boost crop production in Ethiopia. Therefore, an investigation was conducted on soil $\mathrm{pH}$ and Av. $\mathrm{P}$ status assessment and mapping at wuchale district. About One hundred sixty one (161) geo-referenced soil samples were collected by using grid survey method. For both soil parameter analysis standard laboratory analysis were followed. In order to predict values for not sampled locations the Ordinary Kriging interpolation was used by ArcGIS10.3 software. The pH of the soil samples ranged from 4.84 to 6.67 and about $98.13 \%$ of all agricultural soils were acidic in reaction. The district has three categories of soil $\mathrm{pH}$ but the majority of the area falls in moderately acidic, strongly acidic and neutral soil $\mathrm{pH}$ which account area share of $51.55 \%, 46.58 \%$ and $1.87 \%$ respectively. Available P ranged from 2 to 64.79 ppm. The available phosphorus level is categorized as low, medium and high which is $26.70 \%, 52.80 \%$ and $20.50 \%$ respectively. The dominating class is medium i.e. (5 to $15 \mathrm{ppm}$ ). Appropriate rate of lime needs to be applied or cultivating acid tolerant crops is recommended for both strongly acidic and moderately acidic soils of the study district to obtain optimum crop yields. The areas which are low in available soil phosphorus level need to be improved by adding organic manures (FYM/Compost) and inorganic fertilizers to boost the agricultural productivity of the study areas.
\end{abstract}

Keywords: Soil pH, Available Phosphorus, Status and Kriging

\section{Introduction}

In Ethiopia, agriculture, which is directly dependent on soil resource, is the mainstay of the majority of the population and major driver of the national economy. Agricultural production has been highly dependent on natural resources for centuries [4]. However, increased human population and other factors have degraded the natural resources in the country thus seriously threatening sustainable agriculture and food security [26]. The problems of land degradation and low agricultural productivity in the country, resulting in food insecurity and poverty, are particularly severe in the rural highlands [18]. Declining soil fertility has also been stressed to be the fundamental impediment to agricultural development and the major reason for the slow growth in food production in Ethiopia [5].

Ethiopia has a long history of intensive agriculture and human settlement particularly in the highlands [4]. Misuse of soils, arising from a desperate attempt by farmers to increase production for the growing population, has resulted in soil quality degradation. It is associated with soil nutrient depletion by repeated cultivation with low external inputs of nutrients and soil erosion caused by long-term deterioration of natural vegetation and intensive cultivation [8, 16, 25]. According to [12], the major causes of nutrient depletion includes farming without replenishing nutrients over time, removal of crop residue, high proportions of cereals in the cropping system, low level of fertilizer use and unbalanced application of nutrients. The loss of soil nutrients in the country is related to cultural practices such as low fertilizer 
use, removal of vegetative cover and burning plant residues or the annual burning of vegetation on grazing land [2].

Soil $\mathrm{pH}$ is a most important chemical property of soil. Most of the plant nutrients are available at slightly acidic to slightly alkaline soil ( $\mathrm{pH} 6.5$ to 7.5). A number of plant nutrients are unavailable at extremely acidic or extremely alkaline soils due to the different reactions in the soil which fix the nutrients and transform them to the state that is unavailable for the plants. It is one of the determining factors in the plant nutrient availability in the soil [10].

Phosphorus (P) is one of the most abundant elements and is essential for plant growth as well as an important component in the developmental processes of agricultural crops [29, 30] Approximately two-thirds of inorganic P and one third of organic $\mathrm{P}$ are not available in soil, especially in soils of variable charges. The availability of $\mathrm{P}$ is influenced by soil organic matter, $\mathrm{pH}$, and exchangeable and soluble $\mathrm{Al}$, $\mathrm{Fe}$, and $\mathrm{Ca}$ [21]. It is generally available to crops at soil $\mathrm{pH}$ of 6 and 7 . When the soil $\mathrm{pH}$ is less than $6, \mathrm{P}$ deficiency increases in most crops. Conventionally, large amounts of lime and inorganic $\mathrm{P}$ fertilizers such as phosphate rocks and Triple Superphosphate (TSP) are used to saturate Al and Fe ions.

The assessment of soil fertility is perhaps the most basic decision making tool in order to impose appropriate nutrient management strategies [6]. The periodic assessment of important soil properties and their responses to changes in land management is necessary to apply appropriate soil fertility management techniques, and to improve and maintain fertility and productivity of soil [27]. Soil testing assess the current nutrient status and provides information regarding nutrient availability in soils which forms the basis for the fertilizer recommendations for maximizing crop yields and to maintain the adequate fertility in soils for longer period.

Soil properties vary spatially from a small to larger area might be due to effect of intrinsic (parent materials and climate) and extrinsic factors such as soil management practices, indigenous fertility status, crop rotation and nature of standing crop [7]. Mapping the spatial variability of soil fertility by applying GIS is also the order of the day to elicit information for current and future uses. Spatial variability maps of different nutrients and its classification clearly show the specific locations of the areas, where attention is required with respect to management of plant nutrients [13]. Soil nutrients availability and spatial distribution need to be studied before planning for nutrient recommendation. Reliable nutrient recommendations are dependent upon accurate soil tests and crop nutrient calibrations based on extensive field research. The actual fertility status of soils has to be assessed before planning for any crop production, which will help in managing the nutrient/fertilizer application to various crops. Therefore, this study was initiated with the objectives of assessing of $\mathrm{pH}$ and available phosphorus status and mapping their distributions in the study district.

\section{Materials and Methods}

\subsection{Descriptions of the Study Area}

The study was conducted at Wachale district which is found in North Shewa zone, Oromia Regional State and 78 kilometers far from Addis Ababa (capital city of Ethiopia) to North and $34 \mathrm{Km}$ from Fitche, the capital city of North shewa zone. The geographical Location of Wachale district ranges from $9^{\circ} 25^{\prime} 2.13^{\prime \prime}$ to $9^{\circ} 48^{\prime} 44^{\prime \prime} \mathrm{N}$ and $38^{\circ} 38^{\prime} 49.02 "$ to $39^{\circ} 08^{\prime} 41^{\prime \prime} \mathrm{E}$. The district has total area of 48,880 hectares and its map is indicated in (Figure 1).

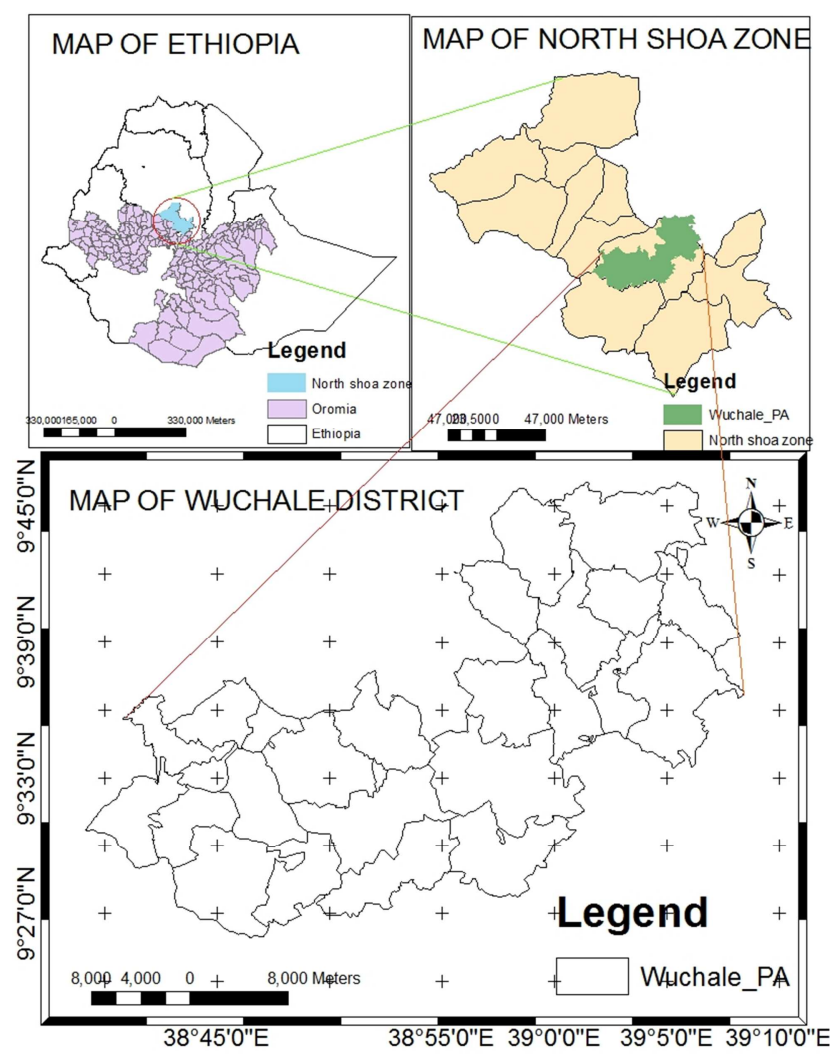

Figure 1. Location map of the study area.

\section{Topography}

The district agricultural information office revealed that larger $(80 \%)$ of Wuchale district are flat or plain while the rugged topography accounts $15 \%$ and the remaining $5 \%$ was plateaus and mountain. The highest elevation of the district is $2880 \mathrm{~m}$, the lowest is $1200 \mathrm{~m}$, and the average elevation is $2412 \mathrm{~m}$ above sea level. That means the districts have the three major classification of landform such as highland, lowland and valley with other minor landform classification [28].

Soil and Geology

According; [28] there are three major soil types in the district such as red soil locally named as "biyyoo diimaa, brown soil locally named as "biyyoo boraalee" and black soil locally named as "biyyoo gurraacha". However, [23] classifies the soil of the district into six dominant soil types. These were Vertisols (68.4\%) which developed on the flat highland of the district and suitable for cultivation of cereals and pulses, Leptosols (26.3\%) which was low in agricultural 
potentials, Cambisols (3.6\%) which was well drained and has relatively good organic content, Luvisols $(0.6 \%)$, Fluvisols, and other soil types constitute the remaining $(1.1 \%)$ from the district soil type.

Climate Condition

The district has four distinct seasons locally named as "Bonaa', 'Arfaasa', 'Ganaa', and Birraa" [28]. The climatic of the district experiences different temperature and rainfall patterns. Though not regular, the district experiences a bimodel rainfall during summer and spring seasons. As Wuchale natural resource management department office of the district [28], the mean annual rainfall is ranged from $1000 \mathrm{~mm}$ $1800 \mathrm{~mm}$ and the lowest temperature is $3^{\circ} \mathrm{C}$, the maximum is $25^{\circ} \mathrm{C}$ and the average temperature is $13.5^{\circ} \mathrm{C}$ in wuchale district.

Vegetation cover

The study area including the present settlement and agricultural land were once covered with indigenous trees and exotic trees mainly Juniperus, Olea abssinica, Hagenia forest, white acacia, Saligim acacia, some podocarpus, thorn forest, Eucalyptus globules etc are the major vegetation found in the district [28]. From this different vegetation, Eucalyptus tree cover the largest percentage and planted around homestead and around farmlands.

Agriculture and farming system

Like other parts of the Ethiopian highlands, the major farming systems of wuchale district were mixed farming; cereal crop cultivation and livestock rearing. Livestock production was the most important agricultural activity next to crop production in the district, which supports the traditional subsistence farming of cereal crops. The crops such as wheat, teff, beans, barley, Chickpea, Lentil, Pea, Flax etc are the major crop in the study area.

Sampling Area Selection

Soil sampling point design has been developed by generating the pre-defined sample points by using grid survey system with $1500 \mathrm{~m} / 1.5 \mathrm{~km}$ interval and taking into consideration the land presently used as crop land and the land not presently used as crop land but which have potential to be converted to crop land. However, the land which is unsuitable for Agriculture has not been included. Then, the pre-defined sampling locations were loaded into GPS as waypoints and navigated the exact location of sampling points.

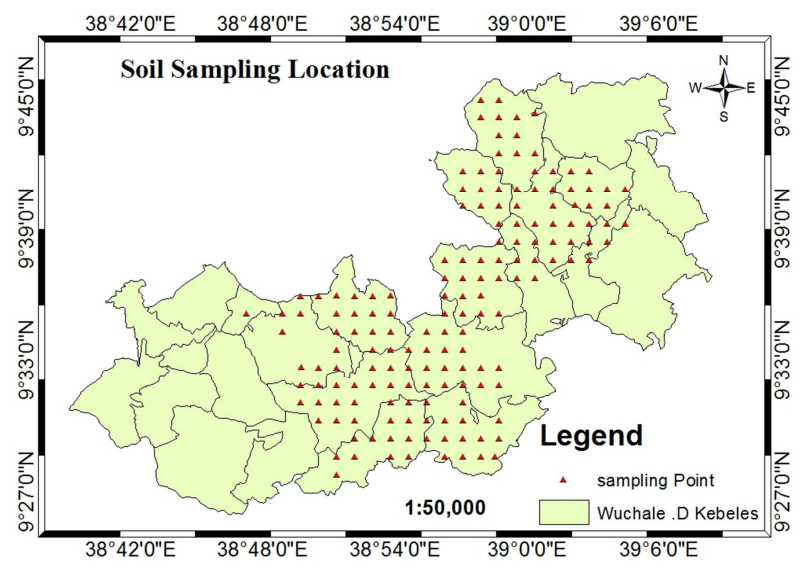

Figure 2. Soil sampling point distribution in the study area.

\subsection{Soil Sample Collection}

Surface soil samples were collected according to [9] through composite sampling technique where sampling points were determined by setting pre-defined sampling points. However, as some pre-defined points were found in unsuitable places for sampling (e.g. road, waterway, and household) they were re-located in alternate locations within nearby cropping fields mostly inside a radius of 50 to 100 meters. Each location was recorded with a Garmin Map $70 \mathrm{~S}$ GPS using Adindan_UTM_Zone_37 N projected coordinates with 3 to 5 meter accuracy.

After reading the coordinate points and elevation of sampling points, slope gradient (\%) of the study area was measured using clinometer by standing in the center of the plot. Then, 8 sub-samples were collected at 15 meters distance in a circle method based on the complexity of topography and heterogeneity of the soil type. In order to address effective root depth of most annual crops, composite soil samples were collected from the top soil $(0-20 \mathrm{~cm})$ for chemical analysis. For perennial/tree crops such as fruit trees, coffee, etc sampling depth was extended to $0-50 \mathrm{~cm}$ downwards.

Soil samples were not taken from restricted areas such as animal dung accumulation places, poorly drained, recently fertilized and any other places that cannot give representative soil samples. During soil sampling, data of spatial information such as land use type, crop type, local soil name, sampling depth, soil color, and crop residue management, history of fertilizer application, rate and type were recorded on site description sheet for each plot. Accordingly, about 161 points were successfully sampled in the District.

\subsection{Laboratory Analysis}

The collected soil samples were air-dried, ground and passed through a $2 \mathrm{~mm}$ sieves for analysis using conventional laboratory methods. Selected soil chemical properties were analyzed at Fitche Agricultural research center laboratory. The analysis was done for $\mathrm{pH}$ and available phosphorous. The methods of analysis for each parameter are presented in the Table below.

Table 1. Methods used in soil parameters analysis.

\begin{tabular}{lll}
\hline No & Soil Parameters & Methods followed \\
\hline 1 & $\mathrm{pH}$ & $\mathrm{pH}-$ meter \\
2 & Av. P & Olsen extraction method (2002) \\
\hline
\end{tabular}

\subsection{Soil Fertility Mapping}

Ordinary kriging was used to predict unknown values of soil nutrients concentration for non sampled areas based on the nearby surveyed data. Point data of selective soil attributes were interpolated across the study area using the geo-statistical model and their spatial prediction were evaluated. Mapping of predicted soil nutrients were carried out by using Arc GIS software version 10.3. After kriging was carried out for selective soil parameters, their classes were defined as low, medium and high for Available 
Phosphorus and Strongly Acidic, Moderately Acidic, Slightly Acidic and Neutral for Soil pH from the map based on [9] critical levels respectively.

\section{Result and Discussion}

The soil nutrient status of the district was assessed with respect to soil $\mathrm{pH}$ and Available Phosphorus. For the whole district mainly two parameters were summarized statistically and overviewed to map their spatial patterns. The total soil samples used were 161 and all samples were collected from agricultural land hence the result mainly represents cultivated lands.

\section{Soil $\mathrm{pH}$}

Soil $\mathrm{pH}$ is considered a master variable in soils as it affects many chemical processes [11]. The soil $\mathrm{pH}$ of the study district ranges from 4.84 to 6.67 with a mean value of 5.63 (Table 2).

Table 2. Soil pH Status of the district Results

\begin{tabular}{ll}
\hline Parameters & $\mathbf{p H}$ \\
\hline Observation Number & 161 \\
Minimum & 4.84 \\
Maximum & 6.67 \\
Mean & 5.63 \\
Standard deviation & 0.36 \\
\hline
\end{tabular}

According to [9] critical levels for soil reaction, the soil $\mathrm{pH}$ value of the district was categorized from strongly acidic $(\mathrm{pH}<5.5)$ to neutral soil $\mathrm{pH}(6.6-7.3)$ (Table 3). Wuchale district has about three categories of soil $\mathrm{pH}$ and about $51.55 \%, 46.58 \%$ and $1.87 \%$ of soil the samples in the district were found to be moderately acidic, strongly acidic and neutral soil $\mathrm{pH}$ respectively (Table 3). Based on this, more than $51 \%$ of the soils were moderately acidic and around 47 of soils were strongly acidic in reaction. The area coverage and percentage share of each categories of soil $\mathrm{pH}$ are illustrated in (Table 3).

Table 3. Area coverage and percentage of each categories of soil pH.

\begin{tabular}{llll}
\hline $\mathbf{p H}$ & Rate & Percentage (\%) & Area (ha) \\
\hline$<5.5$ & Strongly Acidic & 46.58 & $22,768.30$ \\
$5.6-6.5$ & Moderately Acidic & 51.55 & $25,197.64$ \\
$6.6-7.3$ & Neutral & 1.87 & 914.06 \\
\hline
\end{tabular}

More of the soils collected from the district (98.13\%) were acidic in reaction (strongly acidic and moderately acidic) which can affect the availability and solubility of some soil nutrients such as $\mathrm{P}$ and thus reduce crop yields. The first reason for the lowest values of soil $\mathrm{pH}$ at the study sites could be high rainfall that results in loss of base forming cations through leaching and drain to streams in runoff generated from accelerated erosion. This enhances the activity of $\mathrm{Al} 3+$ and $\mathrm{H}+$ in the soil solution, which reduces soil $\mathrm{pH}$ and thereby increases soil acidity.

The soils in the high altitude and higher slopes had low $\mathrm{pH}$ values, probably suggesting the washing out of basic cations from these parts [17]. Continuous cultivation practices and excessive precipitation could also be some of the factors responsible for the reduction of $\mathrm{pH}$ in soils at the middle and upper elevation areas [3]. Although soil acidity is naturally occurring in some areas, human activity can change the $\mathrm{pH}$ of a soil too; agricultural practices have accelerated the process of soil acidification [15].

Hence, the second reason might be continuous use of ammonium based fertilizers such as diammonium phosphate, (NH4)2HPO4, in such cereal based cultivated fields, which upon its oxidation by soil microbes produce strong inorganic acids. These strong acids in turn provide $\mathrm{H}+$ ions to the soil solution that in turn lower soil $\mathrm{pH}$ [1]. Moreover, long-term usage of urea, replacement of ammonium with basic cations and production of hydrogen ion during nitration process, decreases the amount of $\mathrm{pH}$ [14]. The spatial patterns of the soil $\mathrm{pH}$ Wachale district seems as shown in (figure 3 ).

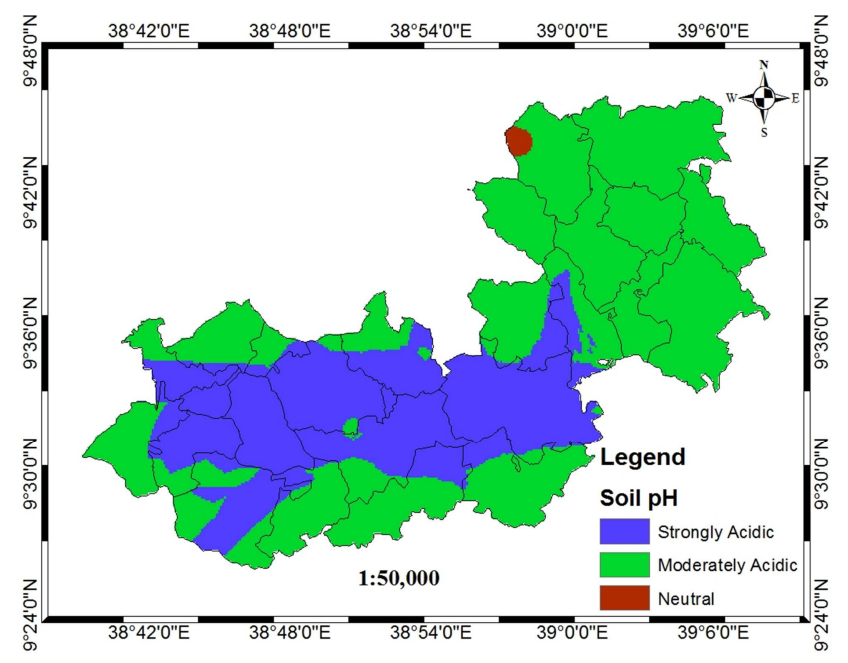

Figure 3. Spatial distributions of soil pH in the district.

Available phosphorus

Phosphorus has been called the "Master key to agriculture" because low crop production is attributed mainly to the deficiency of phosphorus, except nitrogen, than the deficiency of other elements [22]. The study revealed that available phosphorus content of the soils of the study area varied from $2 \mathrm{mg} \mathrm{kg}^{-1}$ to $64.79 \mathrm{mg} \mathrm{kg}^{-1}$ with a mean value of $11.71 \mathrm{mg} \mathrm{kg}^{-1}$ (Table 4).

Table 4. Soil Available Phosphorus Status of the district.

\begin{tabular}{ll}
\hline Parameters & Available $\mathbf{P}(\mathbf{p p m})$ \\
\hline Observation Number & 161 \\
Minimum & 2 \\
Maximum & 64.79 \\
Mean & 11.71 \\
Standard deviation & 11.45 \\
\hline
\end{tabular}

According to the critical values for the Olsen extractable Phosphorus established by [24] for some major and/or agriculturally important Ethiopian soils, the amount of available $\mathrm{P}$ observed from the total samples collected and predicted area, nearly $27 \%$ of available phosphorus values falls under low category and the rest exhibited in medium and high ranges (Figure 4). Similarly, according to [20], $26.70 \%$ of available phosphorus values fall under low 
category, $52.80 \%$ falls under medium category and $20.50 \%$ falls under high category from the total soil samples collected from the district (Table 5). The dominating class is medium which is 5 to 15 ppm of available phosphorus and accounts around $53 \%$ of the area where as the least dominant was high which was $20.50 \%$ of the area. The area coverage and percentage share of each categories of soil available phosphorus are illustrated in (Table 5).

Table 5. Area coverage and percentage of each categories of soil available phosphorus.

\begin{tabular}{llll}
\hline $\begin{array}{l}\text { Available } \\
\text { Phosphorus (ppm) }\end{array}$ & Class Name & Percentage (\%) & Area (ha) \\
\hline$<5$ & Low & 26.70 & 13050.96 \\
$5-15$ & Medium & 52.80 & 25808.64 \\
$>15$ & High & 20.50 & 10020.40 \\
\hline
\end{tabular}

About $26 \%$ and $53 \%$ of the agricultural soils were falls under low and medium category respectively. The reason for the low to medium available phosphorus contents of soils of the district could be continuous uptake by crops, crop residue removal, and low inherent available phosphorus content of the parent material. This suggestion is in line with [19] who reported that, deficiency of available phosphorus is resulted due to losses through crop harvest and erosion. In agreement to this, deficiency of available phosphorus could be one of the major limiting factors to boost crop productivity in the study area. In general, existence of low contents of available phosphorus is a common characteristic of most of the soils in Ethiopia [19] which is similar to the available phosphorus content observed in the soils of the present study area. The map of spatial patterns of the available phosphorus for the Wuchale district is illustrated in the (Figure 4).

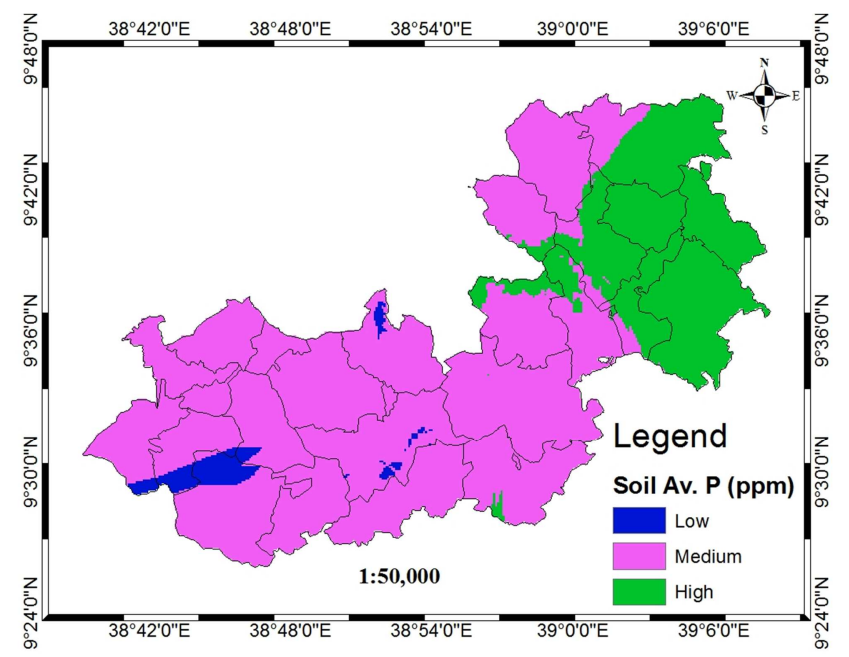

Figure 4. Spatial distributions of soil Available phosphorus in the district.

\section{Conclusion and Recommendation}

Based on the study has been done the soil fertility status for Wuchale district can be concluded for two parameters were as summarized and mapped for the district. The study revealed that Soil $\mathrm{pH}$ of the district has about three categories but the majority of the area falls in moderately acidic and strongly acidic. Soil $\mathrm{pH}(\mathrm{H} 2 \mathrm{O})$ in the study area ranged from 4.84 to 6.73 and rated as strongly acidic to neutral status. However, more of the soils collected from the district were acidic in reaction which can affect the availability and solubility of some soil nutrients such as available phosphorus and thus reduce crop yields. Therefore, appropriate rate of lime needs to be applied or cultivating acid tolerant crops is recommended for both strongly acidic and moderately acidic soils of the study district to obtain optimum crop yields. The results of available phosphorus level was categorized as low, medium and high which was $26.70 \%, \quad 52.80 \%$ and $20.50 \%$ respectively but the dominating class was medium i.e. (5-15ppm). About $27 \%$ of the agricultural soils were falls under low category. Therefore, the areas which are low in available soil phosphorus level need to be improved by adding organic manures (FYM/Compost) and inorganic fertilizers to boost the agricultural productivity of the study areas.

\section{Acknowledgements}

We would like to acknowledge Oromia Agricultural Research Institute for financial support provided during whole activity and also extend especial gratitude to $\mathrm{Mr}$. Getachew Haile, GIS researcher, for his valuable support during soil fertility map development.

\section{References}

[1] Abebe Nigussie and Endalkachew Kissi. 2012. Physicochemical characterization of Nitisols in Southwestern Ethiopia and its fertilizer recommendation using NuMaSS. Global Advanced Research Journal of Agricultural Science, 1 (4): 066-073.

[2] Abebe M. Nature and management of Ethiopian soils. East Hararge, Ethiopia: Alemaya University of Agriculture; 1998. p. 272.

[3] Ahmed Hussein, 2002. Assessment of spatial variability of some physico- chemical properties of soils under different elevations and land use systems in the western slopes of Mount Chilalo, Arsi. MSc thesis, Alemaya University, Ethiopia.

[4] Amsalu A, Stroosnijder L, Graaf G. Long-term dynamics in land resource use and the driving forces in the Beressa watershed, highlands of Ethiopia. J Environ Manage. 2007; 83: $448-59$.

[5] Asfaw B, Heluf G, Yohannes U, Eylachew Z. Effect of crop residues on grain yield of sorghum (Sorghum bicolor) to application of N and P Fertilizers. Nutr Cycl Agecosys. 1997; 48: 191-6.

[6] Brady, Nyle C. and Well, Ray R 2002. The Nature and properties of soils. $13^{\text {th }}$ ed. USA.

[7] Cambardella CA, Karlen DL. Spatial analysis of soil fertility parameters. Precision Agriculture. 1999; 1 (1): 5-14. 
[8] E. Karltun, M. Lemenih, and M. Tolera, "Comparing farmers' perception of soil fertility change with soil properties and crop performance in beseku, ethiopia," Land Degradation and Development, vol. 24, no. 3, pp. 228-235, 2013.

[9] Ethiosis (Ethiopia Soil Information System). Soil fertility status and fertilizer recommendation atlas for Tigray regional state, Ethiopia. Ethiopia; 2014.

[10] Hajabbasi, A. Jalalinat and H. R. Karizdadeh, Deforestation effects on soil physical and chemical properties, Lordegan, Iran. Plant Soil, 1997, 190: 301-307.

[11] Havlin HL, Beaton JD, Tisdale SL, et al. Soil Fertility and Fertilizers- an introduction to nutrient management. 7th ed. India: PHI Learning Private Limited; 2010.

[12] International Food Policy Research Institute (IFPRI) (2010). Fertilizer and soil fertility potentials in Ethiopia. Working Paper, Addis Ababa, Ethiopia.

[13] Jatav, M. K., Dua, V. K., Kumar, M., Trehan, S. P. and Kumar, S. 2013. Spatial distribution of soil available Nutrients in the potato growing pockets of Hoshiarpur district of Punjab. Potato Journal, 40 (2): 128-134.

[14] Juo A, Franzluebbers K., Dabiri A, Ikhile B (1996). Soil Properties and crop performance on kaolintic alison after 15 years of fallow and continuous cultivation. Plant Soil, 180: 209-217.

[15] Kizilkaya R, Dengiz O (2010). Variation of land use and land cover effects on some soil physico-chemical characteristics and soil enzyme activity. Zemdirbyste Agriculture, 97 (2): 1524.

[16] Meshesha, A. Tsunekawa, and M. Tsubo, "Continuing land degradation: cause-effect in Ethiopia's Central Rift Valley," Land Degradation and Development, vol. 23, no. 2, pp. 130143, 2012.

[17] Mohammed A, Roux PAL, Barker CH, et al. Soils of Jelo micro-catchment in the Chercher Highlands of Eastern Ethiopia: I. Morphological and physio-chemical properties Ethiopian Journal of Natural Resources. 2005; 7 (1): 5581 .

[18] Nedessa, B., Ali, J., and Nyborg, I. 2005. Exploring ecological and socio-economic issues for the improvement of area enclosure management: Case Study from Ethiopia. Dry Lands Coordination Group Report No. 38. Oslo, Norway.

[19] Nega Emiru and Heluf Gebrekidan. 2013. Effect of land use changes and soil depth on soil organic matter, total nitrogen and available phosphorus contents of soils in Senbat Watershed, Western Ethiopia. ARPN Journal of Agricultural and Biological Science, 8 (3): 1990-6145.

[20] Olsen, S. R., C. V. Cole, F. S. Watanabe and L. A. Dean, 1954 Estimation of available phosphorus in soils by extraction with sodium carbonate. USDA circular 939: 1-19.

[21] P. Smithson, "Special issue on phosphorus availability, uptake and cycling in tropical agroforestry," Agroforestry Forum, vol. 9, no. 4, pp. 37-40, 1999.

[22] Singh G, Sharma M, Manan J, et al. Assessment of Soil Fertility Status under Diferent Cropping Sequences in District Kapurthala. J Krishi Vigyan. 2016; 5 (1): 1-9.

[23] Strengthening Emergency Response Abilities (SERA) Project, (2000); prepared with support of United State Agency for International Development (USAID), Wuchale District, Oramia Region, Ethiopia.

[24] Tekalign Tadesse. 1991. Soil, plant, water, fertilizer, animal manure and compost analysis. working document No. 13. International Livestock Research Center for Africa, Addis Ababa.

[25] Tesfahunegn, "Soil quality indicators response to land use and soil management systems in northern ethiopia's catchment," Land Degradation and Development, 2013.

[26] Tsegaye G, Bekele W. Farmers' perceptions of land degradation and determinants of food security at Bilate watershed, Southern Ethiopia. Ethio J Appl Sci Technol. 2010; 1: 49-62.

[27] Wakene and Heluf, "Forms of phosphorus and status of available micronutrients under different land-use systems of Alfisols in Bako area of Ethiopia," Ethiopian Journal of Natural Resources, vol. 5, pp. 17-37, 2003.

[28] WDNRMD (Wuchale District Natural Resource Management Department), (2013). First quarter report. (Unpublished, February, 2013); MukeTuri, Oromia regional state, Ethiopia.

[29] Withers, P. J. A., Jarvie, H. P. 2008. Delivery and cycling of phosphorus in rivers, A review. Sci. Total Environ. 400, 379395.

[30] Zhao Y, Wang P, Li J, Chen Y, Ying X, Liu S. Effects of two organic manures on soil properties and crop yields on a temperate calcareous soil under a wheat-maize cropping system. Eur J Agron. 2009; 31: 36-42. 